\title{
Systematic Review about the Effects of Qigong Therapeutic Exercise on Balance
}

Elena Mejías Gil ${ }^{1 *}$ and María Victoria González López-Arza ${ }^{2}$

${ }^{1}$ University of Extremadura, Avda de Elvas S/N, 06006 Badajoz, España, Spain

${ }^{2}$ Medicine and Surgery Department, University of Extremadura, Spain

*Corresponding author: Elena Mejías Gil, Physiotherapist, University of Extremadura, Avda de Elvas S/N, 06006 Badajoz, España, Spain, Tel: 606192836; E-mail: elenamejias92@gmail.com

Received date: March 23, 2017; Accepted date: March 29, 2017; Published date: March 31, 2017

Copyright: (c) 2017 Gil EM, et al. This is an open-access article distributed under the terms of the Creative Commons Attribution License, which permits unrestricted use, distribution, and reproduction in any medium, provided the original author and source are credited.

\section{Abstract}

Objectives: The aim of this study was to review the effects achieved by the Qigong on balance in the last 17 years publications.

Design: The performed search included quantitative researches about the effects of Qigong on balance, published between $01 / 01 / 2000$ and $12 / 31 / 2016$. There was no language restriction and reviews were not included in the analysis.

Databases: PubMed, CSIC, Cochrane Library, Scopus, PEDro, Dialnet, JSTAGE, JTCM

Results: A total of 2966 studies were founded, 11 of them were selected after having applied the established inclusion and exclusion criteria.

Conclusion: Currently, there is not enough evidence to conclusively demonstrate the benefits of Qigong in improving balance. However, based on the analyzed studies, we can say that there are signs of an improvement.

Keywords: Qigong; Qi Gong; Balance; Exercise

\section{Introduction}

Balance can be defined as the posture in which an ideal body mass distribution is achieved. Postural balance provides the body carriage stability and conditions for normal functions in stationary position or in movement, such as sitting, standing, or walking [1].

We can observe, through the literature, how balance is regulated by the vestibular, visual and proprioceptive systems, all of them working together in order to maintain body stability. The different components making up these systems collect information about our position and our posture in the environment and sent it to the centres of balance located into the brain. There, this information is processed in order to provide an integrated response according to the needs. Signals are sent through the spinal cord to regulate the interaction between facilitation and inhibition of the antigravity muscles [2-6].

Due to this complex interaction, balance can be altered in different ways and in some diseases such as Parkinson's disease (PD) and multiple sclerosis (MS) [7-19]. Apart from pathological condition and sedentary habits a bad proprioception can also modify balance capacity in a healthy person. Aging can also affect it because over time, our joints and muscles deteriorate, we lose vision and hearing ability and all this has negative effects on the sense of balance [20,21].

In any of these situations, the individual finds their functional capacity for daily life activities reduced, which, in addition to decrease their quality of life, makes them more prone to falls, increasing the risk of injury and even death $[16,20,22,23]$. The latest figures from National
Statistics Institute quantified deaths from accidental falls during 2013 in 2,672 deceased [24].

Studies show that exercise can be a great help in maintaining and improving balance [22,25-27]. It has been shown to improve physical abilities such as strength and muscular endurance, cardiovascular rhythm, flexibility and proprioception $[25,26]$. However, adherence to treatment is often the main problem to achieve the objectives, because some exercises can be too demanding or difficult to include in the daily routine [27-29]. Therefore, it is still investigating therapies equally effective but less physically demanding.

Qigong is a therapeutic exercise based on the principles of traditional Chinese medicine (TCM) whose culture has practiced for over 3000 years $[13,16]$. His name can be interpreted as "breathing training" $[16,30,31]$, meaning that relates to the basic techniques that are part of Qigong: postural, mental and breath control [13-19].

The scientific evidence gathered by Jahnke [31] suggests that Qigong has beneficial effects on the balance, and improve the cardiopulmonary system, bone density, coordination and proprioception, among others. However, few studies concerning balance were found.

As Blake et al. [15] outlained, Qigong practice has some advantages, e.g it does not require specific instruments and the quietness of its movements represents a low-impact exercise that can be practiced by a wide range of patients. This gives a great potential as an adjunct to conventional treatment methods.

Considering the above, the aim of this study was to review the effects achieved by the Qigong on balance in the last 17 years publications. 


\section{Material and Methods}

\section{Eligibility criteria}

To be included in this systematic review, studies should be quantitative researches about the effects of Qigong on balance, published between January 01, 2000 and December 31, 2016.

Publication who had not studied the improvement of balance or not used Qigong as technique were excluded as well as those which did not follow the typology of selected studies. There was no language restriction and reviews were not included in the analysis.

\section{Data sources}

The following data bases were used to conduct literature searches: MEDLINE-PubMed, Spanish National Research Council [Consejo Superior de Investigaciones Científicas, CSIC], Cochrane Library, Scopus, Physiotherapy Evidence Database (PEDro), Dialnet, Japan Sicience and Technology Information Agregator Electronic (J-STAGE) and the website of Journal of Traditional Chinese Medicine (JTCM).

\section{Search strategy}

We use several combinations of MeSH terms "Qigong", "Qi Gong", "balance", "balance disorders", "brain injuries," "stability", "Parkinson" and "multiple sclerosis" as well as the terms "elder adults "and" older adults" using the Boolean operators AND and OR. We use the same combinations for all databases and their Spanish equivalent for Dialnet.

\section{Study selection}

Two independent authors reviewed the selected articles to be included. In case of disagreement, results were discussed in order to reach a consensus between both researchers. As a general rule, we performed a screening of those studies that followed the line of the chosen issue.

After having selected the articles, we proceeded to read their summaries, excluding those items that did not meet the above reflected inclusion and exclusion criteria. Studies that successfully passed this stage, went to the last one, which included their complete reading for analysis and inclusion in the review.

Data extracted from reading were: author, objective, number of participants, intervention, assessment tools, assessment and results.

\section{Methodological quality}

The methodological quality of the included studies was assessed using the PEDro scale [32]. It consists of 11 items with answers "yes" $(\mathrm{Y})$ or "no" $(\mathrm{N})$, and a total score range of 0-10 which means low or excellent methodological quality.

The 11 items assessed by PEDro scale were: 1. Specification of eligibility criteria; 2. Random assignment; 3. Hidden allocation; 4 . Similar baseline; 5. Blind subjects; 6 . Blind therapist; 7. Blind assessors; 8. Measurement of key outcomes (at least, from $85 \%$ of the subjects); 9 . Analysis of intention to treat; 10. Statistical comparisons between groups; 11 . Measures of variability and point measures.

The values obtained are considered high quality if the score is greater than 5 (6-8: good, 9-10: excellent); moderate quality, if the score is 4 or 5 (limited study); low quality, if the score is less than 4 (poor study) [33].

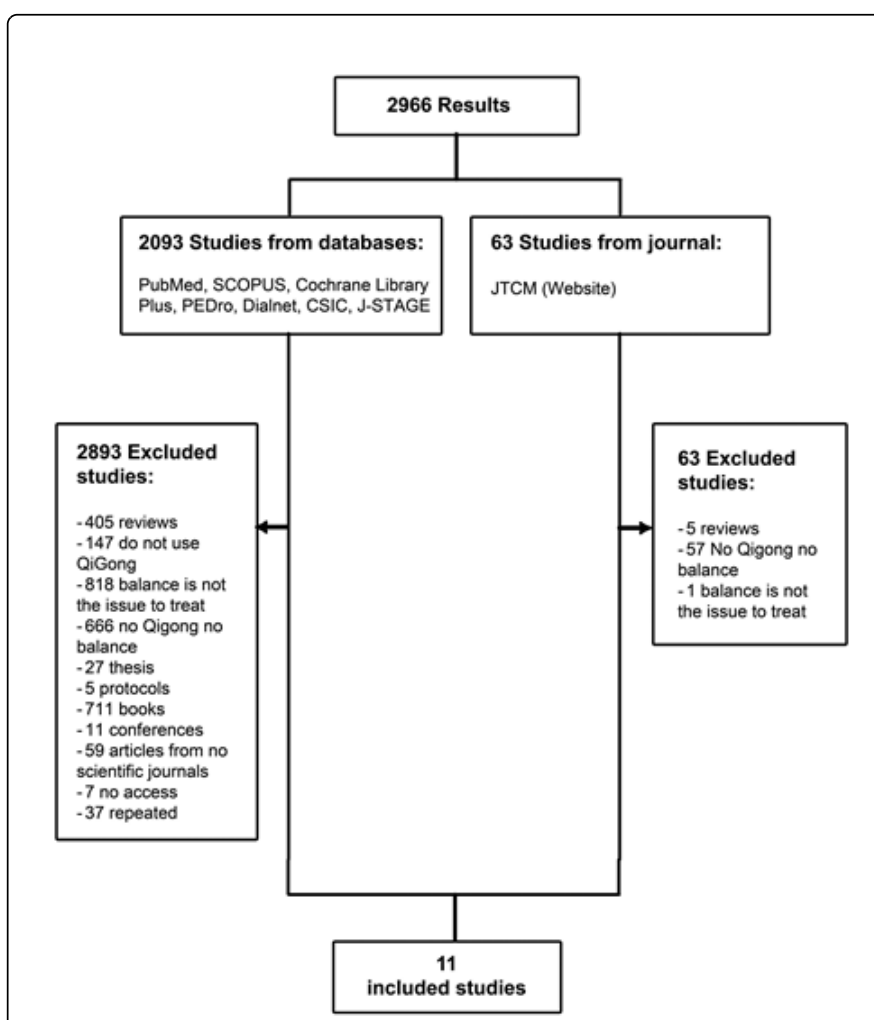

Figure 1: Selection procedure of the studies from the literature search.

\section{Results}

A total of 2966 studies were founded, 11 of them were selected after having applied the established inclusion and exclusion criteria. The process of search and selection of studies is detailed in Figure 1 Selection procedure of the studies from the literature search. The main characteristics of the selected studies are reflected in Table 1 Summary of included studies.

\section{Studies description}

\section{Subjects}

A total of $45 \%$ of these publications were pilot studies with a small sample size in some cases [9]. This means that the number of subjects in the articles ranged between 8 and 120, which focuses the average in 41 and gave us a total of 591 participants. Only three of these studies referred to have calculated the sample size needed to be representative $[10,15,17]$. Total 561 subjects had balance problems, due either to illness or age ( $80.4 \pm 8.6$ years). The remaining 30 were young healthy individuals without any associated pathology. Among diseases we founded: Parkinson's (PD), Fibromyalgia (FM), Muscular Dystrophy (MD), Traumatic Brain Injuries (TBI), nasopharyngeal cancer (NPC) and coronary artery disease (CAD). 
Citation: Gil EM, López-Arza MVG (2017) Systematic Review about the Effects of Qigong Therapeutic Exercise on Balance. Altern Integr Med 6:

Page 3 of 6

\section{Intervention period}

The length of the treatment periods ranged from one to six months, without rest or follow-up stages. This clarification is necessary because one of the articles was a crossover study and it applied a rest period in between each treatment phase [11].

\section{Measurement instruments}

Just a few studies agree to use the same balance assessment scale. The most used was a single leg stance test $[9,12,16,17]$ but other preferred to use other forms of measurement as the Berg Balance Scale $[11,18,19]$ or a sensory organization test $[14]$.

\section{Effects on balance}

Most studies points to a significant improvement of balance after using Qigong as training [9,12-14,16-19].

Mills and Loftus, who worked without a control group, compared the results before and after the treatment among their patients with MS and PD respectively. In the first case, they used a single leg stance test, in which they saw an improvement from 5.63 seconds in stance to 11.88. The second author used the Berg Balance Scale and he detected and improvement from 32.79 to 37.06 points $(\mathrm{P}=0.001)$.

The remaining authors compared their results with a control group. Among them, only Yang et al. [14] used a Sensory Organization Test, which allowed them to detect a bigger improvement at balance controlled by vestibular area $(\mathrm{P}>0.01)$.

Blake et al. [15] found no significant differences between the results before and after the treatment of Qigong nor any related improvement.

Regarding the remaining two authors, they are in an intermediate position between these two outcome groups. Both Wenneberg et al. [11] and Mannerkorpi et al. [10] saw in their studies, although there was no significant difference between before and after treatment results, the Qigong group did not get worse in its scores while the control group did it. This deterioration was reported as significant by both Mannerkorpi $(\mathrm{P}<0.04)$ and Wenneberg $(\mathrm{P}<0.025)$.

Wenneberg et al. [11] calculated that a sample of 54 patients would provide significant differences between the study groups. Moreover, Mannerkorpi detected an improvement of proprioception and movement harmony at the end of treatment $(\mathrm{P}=0.03)$.

\section{Methodological quality}

The methodological quality scores got by the articles according to the PEDro scale [32] are reflected in Table 1. The mean of these scores is around 5 point; the lowest score is 2 and the highest 8 .

\begin{tabular}{|c|c|c|c|c|c|c|}
\hline AUTHOR & OBJETIVE & SAMPLE & INTERVENTION & $\begin{array}{l}\text { MEASURING } \\
\text { INSTRUMENTS }\end{array}$ & $\begin{array}{l}\text { MAIN BALANCE } \\
\text { RESULTS }\end{array}$ & $\begin{array}{l}\text { PEDro } \\
\text { SCALE }\end{array}$ \\
\hline Mils 2000 & $\begin{array}{l}\text { To provide some preliminary } \\
\text { data on the usefulness of } \\
\text { TJ/QG for people with MS }\end{array}$ & $\mathrm{N}=8$ (MS) & $\begin{array}{l}\text { Single-sample } \\
2 \text { months baseline } \\
2 \text { months intervention } \\
\text { (TJ-QG } 30 \text { min/day) }\end{array}$ & $\begin{array}{l}\text { 1) Check-list of physical } \\
\text { symptoms } \\
\text { 2) One leg-standing test }\end{array}$ & $\begin{array}{l}\text { 1) } \quad \text { Participants } \\
\text { improvement } \\
\text { responses: } 32 \% \\
\text { 2) } \uparrow(P<0.05)\end{array}$ & $2 / 10$ \\
\hline Mannerkorpi 2004 & $\begin{array}{l}\text { To evaluate the effects of } \\
\text { body awareness therapy } \\
\text { combined with QG for FM }\end{array}$ & $\mathrm{N}=36(\mathrm{FM})$ & 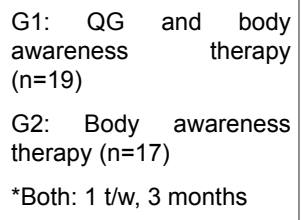 & $\begin{array}{l}\text { 1) Body Awareness Rating } \\
\text { Scale } \\
\text { 2) Physical Function Test }\end{array}$ & $\begin{array}{l}\text { 1) } \mathrm{G} 1 \uparrow(P=0.03) \\
\text { 2) } \mathrm{NS}\end{array}$ & $5 / 10$ \\
\hline Wenneberg 2004 & $\begin{array}{l}\text { To evaluate the effects of QG } \\
\text { for MD patients }\end{array}$ & $\mathrm{N}=36(\mathrm{MD})$ & $\begin{array}{l}\text { Phase 1: (3 months) } \\
\text { G1: QG }(n=16) \\
\text { G2: Control( }(n=15) \\
\text { Phase 2: }(3 \text { months) } \\
\text { G1a:Control }(n=7) \\
\text { G1b QG }(n=9) \\
\text { G2: QG }(n=12)\end{array}$ & Berg's Balance Scale & $\begin{array}{l}\text { Inter-group: } \\
\text { NS } \\
\text { Intra-group: } \\
\text { QG remain, control } \\
\text { worsen }(p=0.025)\end{array}$ & $6 / 10$ \\
\hline Stenlund 2005 & $\begin{array}{l}\text { To investigate whether the QG } \\
\text { would increase physical ability } \\
\text { for elderly patients with } C A D\end{array}$ & $\mathrm{~N}=95$ (CAD) & $\begin{array}{l}\text { G1: QG: } 1 \mathrm{~h}, 1 \mathrm{t} / \mathrm{w}, 3 \\
\text { months }(n=48) \\
\text { G2: Control }(n=47)\end{array}$ & $\begin{array}{l}\text { 1) Self-estimated level of } \\
\text { physical activity scale } \\
\text { 2) Falls Efficacy Scale } \\
\text { 3) Berg's Balance Scale } \\
\text { 4) One leg-standing test } \\
\text { 5) Coordination }\end{array}$ & $\begin{array}{l}\text { Inter-group: } \\
\text { 1) } G 1 \quad \text { improve } \\
(P<0.01) \\
\text { 2) and 3) NS } \\
\text { 4) } G 1 \quad \text { improve } \\
(P=0.029) R L \\
\text { 5) G1 improve } \\
\text { Intra-group: }\end{array}$ & $5 / 10$ \\
\hline
\end{tabular}


Citation: Gil EM, López-Arza MVG (2017) Systematic Review about the Effects of Qigong Therapeutic Exercise on Balance. Altern Integr Med 6:

\begin{tabular}{|c|c|c|c|c|c|c|}
\hline & & & & & $\begin{array}{l}\text { 4) G1 improve both } \\
\text { legs }\end{array}$ & \\
\hline $\begin{array}{l}\text { Schmitz-Hübsch } \\
\text { (2006) }\end{array}$ & $\begin{array}{l}\text { To evaluate the effects of QG } \\
\text { on motor and no-motor } \\
\text { symptoms of PD }\end{array}$ & $\mathrm{N}=56(\mathrm{PD})$ & $\begin{array}{l}\text { G1: QG: } 60 \text { min, } 1 \text { t/w for } \\
2 \text { months }+ \text { rest for } 2 \\
\text { months }+2 \text { months } \\
\text { intervention } \\
\text { conditions). } \\
\text { G2: Control }\end{array}$ & 1) UPDRS-III & $\begin{array}{l}\text { 1) Improvement due } \\
\text { to QiGong at } 3 \\
\text { months } \quad(P=0.008) \\
\text { and at } 6 \text { months } \\
(P=0.05)\end{array}$ & $5 / 10$ \\
\hline Yang 2007 & $\begin{array}{l}\text { To evaluate changes in } \\
\text { balance mechanisms of } \\
\text { healthy older adults as } \\
\text { consequence of TJ-QG } \\
\text { sequence }\end{array}$ & $\mathrm{N}=49$ & $\begin{array}{l}\text { G1: TJ-QG: } 1 \mathrm{~h}, 3 \mathrm{t} / \mathrm{w} \text { for } \\
6 \text { months }(n=33) \\
\text { G2: Control }(n=16)\end{array}$ & $\begin{array}{l}\text { 1) } \mathrm{SOT} \\
\text { 2) } \mathrm{BoS}\end{array}$ & $\begin{array}{l}\text { 1) } \uparrow \text { vestibular score } \\
\text { (T2:+22\%, } \\
\mathrm{T} 6:+47 \%) \text { for } \mathrm{G} 1 \\
2) \uparrow \text { stability at } \mathrm{G} 1\end{array}$ & $5 / 10$ \\
\hline Blake 2009 & $\begin{array}{l}\text { To examine the effects of a } \\
\text { TJ-QG sequence on } \\
\text { individuals with TBI }\end{array}$ & $\mathrm{N}=20(\mathrm{TBI})$ & $\begin{array}{l}\text { G1: QG: } 1 \text { h/w, } 8 w \\
\text { G2: Control }\end{array}$ & $\begin{array}{l}\text { 1) PSDQ } \\
\text { a. Coordination } \\
\text { b. Self-esteem } \\
\text { c. Flexibility }\end{array}$ & 1) NS & $6 / 10$ \\
\hline $\begin{array}{l}\text { Gonzalez Lopez-Arza } \\
2013\end{array}$ & $\begin{array}{l}\text { To describe the change in } \\
\text { balance in young, healthy } \\
\text { women after } \\
\text { Practising QG }\end{array}$ & $\mathrm{N}=30$ & $\begin{array}{l}\text { G1: QG: } 1 \text { h } 2 \text { t/w, } 4 \mathrm{w} \\
\text { G2:Control }\end{array}$ & 1) One leg-standing test & $\begin{array}{l}\text { Intra-group } \\
\text { G1 } \uparrow \text { from } 40.15 \% \text { to } \\
56.46 \% \\
\text { Inter-group } \\
\text { NS }\end{array}$ & $4 / 10$ \\
\hline Fong 2014 & $\begin{array}{l}\text { To compare the one-leg- } \\
\text { stance time and the } 6 \mathrm{MWT} \\
\text { distance among TJ-QG- } \\
\text { trained NPC survivors, } \\
\text { untrained NPC survivors, and } \\
\text { healthy individuals }\end{array}$ & $\begin{array}{l}\mathrm{N}=120 \\
(50 \mathrm{NPC}, 68 \\
\text { healthy } \\
\text { people })\end{array}$ & $\begin{array}{l}\text { G1: NPC-QG }(n=25) \\
\text { G2: } \\
\text { GPC-Control }(n=25) \\
\begin{array}{ll}(n=68) & \text { Healthy control } \\
\text { * } & \text { Cross-sectional } \\
\text { exploratory study }\end{array}\end{array}$ & $\begin{array}{l}\text { 1) } 6 \mathrm{MWT} \\
\text { 2) One leg-standing test in } \\
\text { different conditions of } \\
\text { viewing and surface }\end{array}$ & $\begin{array}{l}\text { 1) NS } \\
\text { 2) } G 1 \text { similar to } G 3 \\
\text { (eyes closed, stable } \\
\text { surface) }(P=0.168)\end{array}$ & $4 / 10$ \\
\hline Loftus 2014 & $\begin{array}{l}\text { To examine the effects of QG } \\
\text { on postural stability and PD- } \\
\text { related falls }\end{array}$ & $\mathrm{N}=41(\mathrm{PD})$ & $\begin{array}{l}\text { One group } \\
\text { QG: } 1 \mathrm{~h}, 2 \mathrm{t} / \mathrm{w}, 3 \text { months }\end{array}$ & $\begin{array}{l}\text { 1) Parkinson's Disease Fall } \\
\text { Profile } \\
\text { 2) Berg Balance Scale } \\
\text { 3) Pull test }\end{array}$ & $\begin{array}{l}\text { 1) } \downarrow \text { falls after } Q G \\
(P=0.004) \\
\text { 2) } \uparrow \text { balance after } \\
\text { QG (P=0.001) } \\
\text { 3) NS }\end{array}$ & $4 / 10$ \\
\hline Xiao 2015 & $\begin{array}{l}\text { To investigate } \\
\text { effectiveness of Q } \\
\text { symptoms related to gait, } \\
\text { functional } \\
\text { mobility and sleep in PD } \\
\text { patients }\end{array}$ & $\mathrm{N}=100(P D)$ & $\begin{array}{l}\text { G1: QG: } 45 \text { min, } 4 \mathrm{t} / \mathrm{w}+ \\
30 \text { min walk, } 6 \text { months } \\
\text { G2:30 min walk, } 6 \\
\text { months }\end{array}$ & $\begin{array}{l}\text { 1) Berg's balance scale } \\
\text { 2) } 6 M W T \\
\text { 3) Time Up\&Go }\end{array}$ & $\begin{array}{l}\text { 1) } G 1 \text { improves } \\
\begin{array}{ll}(P=0.041) & \\
\text { 2) } \quad G 1 & \text { improves } \\
(P=0.042) & \\
3) \quad G 1 & \text { improves } \\
\text { 3) } P=0.046) & \end{array}\end{array}$ & $8 / 10$ \\
\hline \multicolumn{7}{|c|}{$\begin{array}{l}\text { TJ-QG: Taiji-Qigong sequence; G: Group; NS: Not Significant; T: Time of evaluation; min: minute; h: hours; t/w: times per week; RL: Right Leg; UPDRS: Unified } \\
\text { Parkinson's Disease Rating Scale; SOT: Sensory organization test; BoS: Base of Support; PSDQ: Physical Self-Description Questionnaire; } 6 \text { MWT: } 6 \text { Minute Walk Test; } \\
\text { FM: Fibromyalgia; MS: Multiple Sclerosis; MD: Muscular Dystrophy; PD: Parkinson Disease; TBI: Traumatic Brain Injury; CAD: Coronary Artery Disease; NPC: } \\
\text { Nasopharyngeal Cancer. }\end{array}$} \\
\hline
\end{tabular}

Table 1: Summary of included studies.

No one of the participants and therapists of these studies were blinded, although four of the researchers blinded the assessors collecting data $[10,11,18,19]$. Apart from two articles $[9,17]$, all authors have mentioned that they randomized their sample and explained the procedure by which it was performed by randomization. Only Mills et al. [9], Fong et al. [17] and Loftus et al. [18] do not included a flow diagram of subjects throughout the study.

\section{Discussion}

Results of this review indicate that Qigong can induce an improvement on balance. This statement is supported by a $72.7 \%$ of the revised trials with only a $9 \%$ of them against. However, we must be cautious when interpreting these results because of the limitations founded through the analyzed studies as well as through this review.

First, the search shows a significant shortage of studies involving Qigong as a technique for improving balance. This may be due to the inclusion criteria, to the lack of knowledge about this modality of 
exercise or a compendium of both. Bearing in mind that this search covered seventeen years of publications, the lack of studies linking these two topics and the fact that half of the collected researches were pilot studies, it provides an idea of what unexploited field it is.

Moreover, there are very few good quality articles on the topic due to the fact that only one of them was over 6 points on the PEDro scale [19]. One of the weaknesses in the design of the articles is the lack on blinding. It is true that in this type of therapy it is impossible to blind the sample or the therapist. However, some studies could have increased the methodological quality blinding assessors as it was done, for example, in the study of Wenneberg et al. [11].

The small sample size is another important aspect of the limitations of some articles that included eight [9] or twenty participants only [15].

On the other hand, one of the strengths shared by all articles was the specification of the sequence of performance of Qigong exercise, an important fact to allow the replication of the work.

We also found a lack of homogeneity in the pathologies that makes a comparison difficult. At this point, it is noteworthy that counting with so little written on this topic, we found only two publications that aim to test the effects of Qigong in the balance of healthy subjects $[14,16]$. Based on only two studies we cannot say that there is clear scientific evidence that Qigong improves balance. However, other authors go on to test it directly as a treatment in patients affected by other pathologies. It is notable that in these studies the effects of Qigong could have be modified by other symptomatology, as well as by the medication these patients were taking and which was not detailed.

Finally, it would be interesting for future researches to assess the level of effectiveness of Qigong separately in different types of balance. If the study by Yang et al. [14] was correct and Qigong has greater benefits for the balance controlled by the vestibular area, when being used as a treatment, Qigong may have a different efficiency depending on the origin of the disease.

Further publication should consider these limitations to provide a more scientific and objective approach to the use of Qigong as an exercise for improving balance.

The conclusions of this work have been carried out from the studies founded by the search strategy as well as by the inclusion criteria proposed. It is necessary to consider the possibility that, due to search limits, other studies have been left out of this review.

\section{Conclusion}

Currently, we do not have enough evidence to allow us to conclusively demonstrate the benefits of Qigong in improving balance. However, based on the analyzed studies, we can say that there are signs of an improvement.

More researches are needed with a more homogeneous methodology and technique as well as with larger sample sizes and improved monitoring, in order to get a better approach to the real degree of effectiveness of Qigong therapeutic exercise for balance improvement.

\section{References}

1. MeSH Database. Nacional Center Biotechnology Information.
2. Hoffman S (2010) How does the balance system works? American Physical Therapy Association.

3. Matsuo T, Yamasaki H, Yasuhara H, Hasebe K (2013) Postural stability changes during large vertical diplopia induced by prism wear in normal subjects. Acta Med Okayama 67: 177-183.

4. Guyton A, Hall J (2006) Medical physiology. 11th edn, Elsevier, Philadelphia, Pennsylvania, pp. 692-696.

5. Quitschal RM, Fukunaga JY, Ganança MM, Caovilla HH (2014) Evaluation of postural control in unilateral vestibular hypofunction. Braz J Otorhinolaryngol 80:339-345.

6. Tomomitsu MS, Alonso AC, Morimoto E (2013) Static and dynamic postural control in low-vision and normal-vision adults. Clinics (Sao Paulo) 68: 517-521.

7. Fukunaga JY, Quitschal RM, Doná F (2014) Postural control in Parkinson's disease. Braz J Otorhinolaryngol 80: 508-514.

8. Oh B, Butow P, Mullan B (2012) A critical review of the effects of medical Qigong on quality of life, immune function and survival in cancer patients. Integr Cancer Ther 11:101-110.

9. Mills N, Allen J, Carey Morgan S (2000) Does Tai Chi/Qi Gong help patients with Multiple Sclerosis? J Bodyw Mov Ther 4: 39-48.

10. Mannerkorpi K, Arndorw M (2004) Efficacy and feasibility of a combination of body awareness therapy and qigong in patients with fibromyalgia: a pilot study. J Rehabil Med. 36: 279-281.

11. Wenneberg S, Gunnarsson LG, Ahlström G (2004) Using a novel exercise programme for patients with muscular dystrophy. Part II: a quantitative study. Disabil Rehabil 26: 595-602.

12. Stenlund T, Lindström B, Granlund M, Burell G (2005) Cardiac rehabilitation for the elderly: Qi Gong and group discussions. Eur J Cardiovasc Prev Rehabil 12: 5-11.

13. Schmitz-Hübsch T, Pyfer D, Kielwein K (2006) Qigong exercise for the symptoms of Parkinson's disease: a randomized, controlled pilot study. Mov Disord 21: 543-548.

14. Yang Y, Verkuilen JV, Rosengren KS (2007) Effect of combined Taiji and Qigong training on balance mechanisms: a randomized controlled trial of older adults. Med Sci Monit 13: 339-348.

15. Blake H, Batson M (2009) Exercise intervention in brain injury: a pilot randomized study of Tai Chi Qigong. Clin Rehabil. 23: 589-598.

16. González López-Arza MV, Varela-Donoso E, Montanero-Fernández J (2013) Qigong improves balance in young women: a pilot study. J Integr Med 11: 241-245.

17. Fong SS, Chung LM, Tsang WW (2014) Balance performance in irradiated survivors of nasopharyngeal cancer with and without tai chi qigong training. Evid Based Complement Alternat Med 2014: 1-7.

18. Loftus SL (2014) Qi Gong to improve postural stability (QTIPS) for Parkinson fall prevention. Top Geriatr Rehabil 30: 58-69.

19. Xiao CM, Zhuang YC (2015) Effect of health Baduanjin Qigong for mild to moderate Parkinson's disease. Geriatr Gerontol Int 16: 911-919.

20. Suarez H, Arocena M (2009) Balance disorders in the elderly. Rev Med Clin Counts 20: 401-407.

21. Suttanon P, Hill KD, Said CM (2012) Balance and mobility dysfunction and falls risk in older people with mild to moderate Alzheimer disease. Am J Phys Med Rehabil 91: 12-23.

22. Wong-Yu IS, Mak MK (2015) Multi-dimensional balance training programme improves balance and gait performance in people with Parkinson's disease: A pragmatic randomized controlled trial with 12month follow-up. Parkinsonism Relat Disord 21: 615-621.

23. Fernández-Cuenca R, Llácer A, López-Cuadrado T, Gómez-Barroso D (2014) Mortality from external causes in Spain. Boletín epidemiológico seminal Vol. 22.

24. http://www.ine.es/en/prodyser/pubweb/anuarios_mnu_en.htm

25. Sharma A, Geovinson SG, Singh SJ (2012) Effects of a nine-week core strengthening exercise program on vertical jump performances and static balance in volleyball players with trunk instability. J Sports Med Phys Fitness 52: 606-615. 
Citation: Gil EM, López-Arza MVG (2017) Systematic Review about the Effects of Qigong Therapeutic Exercise on Balance. Altern Integr Med 6: 236. doi:10.4172/2327-5162.1000236

Page 6 of 6

26. Matrangola SL, Madigan ML (2009) Relative effects of weight loss and strength training on balance recovery. Med Sci Sports Exerc 41: 1488-1493.

27. Laufer Y, Dar G, Kodesh E (2014) Does a Wii-based exercise program enhance balance control of independently functioning older adults? A systematic review. Clin Interv Aging 9: 1803-1813.

28. Yost TL, Taylor AG (2013) Qigong as a novel intervention for service members with mild traumatic brain injury. Explore (NY) 9: 142-149.

29. Lee MS, Ernst E (2009) Qigong for movement disorders: A systematic review. Mov Disord 24: 301-303.
30. Gallagher (2003) Tai chi chuan and qigong: physical and mental practice for functional mobility. Topics in Geriatric Rehabilitation 19: 172-182.

31. Jahnke R, Larkey L, Rogers C (2010) A comprehensive review of health benefits of qigong and tai chi. Am J Health Promot 24: e1-e25.

32. www.pedro.org.au/spanish/downloads/pedro-scale/

33. De Morton NA (2009) The PEDro scale is a valid measure of the methodological quality of clinical trials: A demographic study. Aust J Physiother 55: 129-133.

34. Fauci A (2012) Harrison's Principles of Internal Medicine. 18th edn, McGrawHill, New York, pp: 151-154. 